\title{
Initiation into Teaching from the Perspective of Primary School Teachers: Differences Between Newly Qualified and Experienced Teachers
}

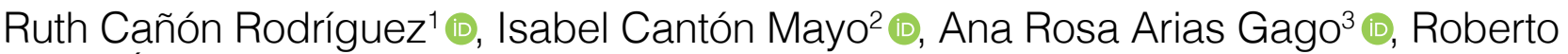 \\ Baelo Álvarez ${ }^{4}$ (]) \\ 'Department of General and Specific Didactics and Educational Theory, Faculty of Education, University of \\ León, Spain \{rcanr@unileon.es\} \\ 2Department of General and Specific Didactics and Educational Theory, Faculty of Education, University of \\ León, Spain \{icanm@unileon.es\} \\ ${ }^{3}$ Department of General and Specific Didactics and Educational Theory, Faculty of Education, University of \\ León, Spain \{ararig@unileon.es\} \\ ${ }^{4}$ Department of General and Specific Didactics and Educational Theory, Faculty of Education, University of \\ León, Spain \{rcanr@unileon.es\}
}

Received on 22 July 2016; revised on 6 October 2016; accepted on 14 November 2017; published on 15 July 2017

\begin{abstract}
This study consists of an investigation into the experiences of new teachers in primary education in the province of León, during their initiation into teaching. The objective was to explore how they experience this stage, and to recognize the training needs that exist along with the degree of motivation and satisfaction expressed with the measures designed for integration into teaching. The methodology used is descriptive and interpretive, ex-post-facto oriented towards a search for improvement.

Research finding reveals the existence of significant gaps in initial teacher training that bears a negative influence on the subsequent professional development of the teachers involved. In this sense, the training programs designed for teachers who are initiating their career, although valued positively by both novices and experienced teachers; do not overcome their initial shortcomings.

Despite the difficulties, however, new teachers show a general feeling of satisfaction with the stage in which they initiate their teaching.
\end{abstract}

KEYWORDS: PRESERVICE TEACHER EDUCATION, INSERVICE TEACHER EDUCATION, TEACHER EDUCATION, PRIMARY TEACHER EDUCATION

\section{INTRODUCTION}

The integration of the Spanish university system into the EHEA has had a positive effect on the extension of the initial training of future teachers. In this context, it is necessary to develop the skills that enable future teachers to train their students through active methodologies that favour a proper balance between skills, knowledge, values and attitudes (Zaragoza, Generelo, \& Julián,

*To whom correspondence should be addressed:

Department of General and Specific Didactics and Educational Theory.

Office 138. Faculty of Education. University of León

24071 León (Spain)
2008). The aim is for them to possess the skills, knowledge and abilities necessary in order to initiate their career in teaching and successfully perform their work in any situation that they may encounter.

This connection between initial training and initiation into teaching is critical in order to minimize the risks associated with the famous "reality shock" (Veenman, 1984), which is suffered by most new teachers when the ideals regarding the teaching profession acquired during their period of instruction are confronted with the educational reality that they find when they begin to actually work within the teaching profession. These changes in the perceptions and ideals of the teacher during her or his initiation to teaching are the axis on which we will coordinate the development of this piece of research, with the intention of finding out how the novice teacher experiences her or his work on coming face to face with and reflecting on the educational reality found in the classroom.

\subsection{Introduction to teaching: Programs for the introduction into teaching}

The initiation into teaching has been defined by various authors, (Feiman-Nemser, 2012; Imbernón, 1994a, 1994b, 2007; Marcelo 2009; Vonk, 1996), as the intermediate period between the initial and continuing teachers training. It "deserve some undivided attention" (Luft, 2007, p. 532), because for some teachers this period is fraught with difficulties (Henry, Bastian, \& Fortaner, 2011; Saka, Southerlands, Kittleson, \& Hutner, 2013) as discipline, classroom management, contradictions between theory and practise, etc. (Saka et al., 2013). Counterbalancing the difficulties of this period should be personally and professionally fulfilling (Skilbeck \& Connell, 2003), offer targeted professional learning (Corbell, Osbourne, \& Rieman, 2010), offer constructive feedback and support (Cuddapah \& Burtin, 2012; Harris, Jenz, \& Baldwin, 2005; Kidd, Brown, \& Fitzallen, 2015; Zepeda \& Ma- 
yers, 2001) and provide support from mentor teachers (Huling, Resta, \& Yeargain, 2012).

At this moment teachers perform a hard relearning in order to face and reflect the reality of classroom teaching practice, launching the lessons that have been acquired during their initial training: "is generally seen as a structured support programme for qualified first-time teachers" (EACEA/Eurydice, 2015, p. 42). During this phase, these teachers carry the tasks as experienced teachers and are remunerated for their work (Darling-Hammond, 2010; EACEA/Eurydice, 2015; Hudson, 2012; Le Maistre \& Paré, 2010).

The profusion of research in this field (Darling-Hammond \& Bransford, 2005; Feiman Nemser, 2001) has led to the emergence of a focus of study around teaching programs for insertion according to Gold (1996), to help the teacher to advance their professional teacher development, because there is knowledge and there are skills that the new teachers can only learn on the job (Curry, Webb, \& Latham, 2016; Feiman-Nemser, 2003).

Induction programs differ in their basic components (Bartlett \& Johnson, 2010; Ingersoll, 2006; Smith \& Ingersoll, 2004; Villani, 2009; Wechsler et al., 2012). These can include participation in seminars, orientation, mentoring, professional network, peer collaboration, reduce workload, professional development, etc. (Hunter, 2016; Ingersoll, 2006, 2012). The most successful induction programs, which include multiple components, are formal, structured and planned. (Bickmore \& Bickmore, 2010; Bickmore \& Curry, 2013; EACEA/Eurydice, 2013; Smith \& Ingersoll, 2004).

Howe (2006) emphasizes that helping new teachers with teaching or mentoring, appears to be a preferred support mechanism. However, Hobson, Ashby, Malderez and Tomlinson (2009), points out that to achieve quality tutoring, it takes a careful selection of mentors; these figures are responsible for the counselling of novice teachers through their experience (Nasser-Abu Ahija \& Fresko, 2010; Sundli, 2007). The role of the mentor is not always used in the same way or with the same purpose depending on countries or educational system (Kemmis, Heikkinen, Fransson, Aspfors, \& Edwards-Groves, 2014). However, Jonson (2002, p. 9) describes the qualities which should have an effective mentor:

(a) being a skilled teacher; (b) being able to transmit effective teaching strategies; (c) having a thorough command of the curriculum being taught; (d) being able to communicate openly with the beginning teacher; (e) being a good listener; (f) being sensitive to the needs of the beginning teacher; $(\mathrm{g})$ understanding that teachers may be effective using a variety of styles; and (h) not being overly judgmental.

We ought not to forget that mentoring can have limitations if not used properly, for example, new teachers can receive little or no support (Wong, 2004).

In Europe, the presence of these programs varies because there are differences in training programs, in access to education and even in relation to permanent training, and different ways are encountered which attempt to address the difficulties which new teachers come across. Figure 1 attempt to show a synthesis of the current situation in Europe based on the document entitled Key figures of teachers and management of schools in Spain (EACEA/ Eurydice, 2013).

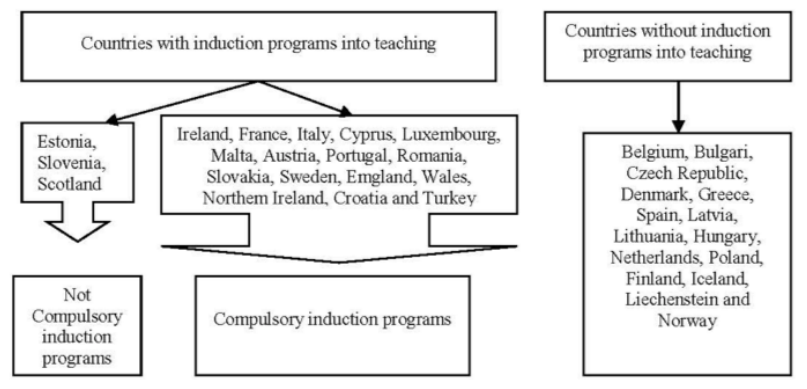

Figure 1. Presence induction programs into teaching in Europe.

According to Figure 1 almost European countries, Spain included, do not have a state system of initiation into the teaching profession. However, they have other measures intended to facilitate the transit of novice teachers in their induction period to teaching, of which the most widespread is the tutoring (Eurydice, 2002; EACEA/Eurydice, 2013).

In Spain the organization of the first year of work for teachers is the responsibility of the Autonomous Communities in accordance with Article 30 of Royal Decree 276/2007, of 23 February (BOE, 2007), and among existing aids we are regular to discuss progress and problems encountered meetings, assisting in the planning and evaluation of classes, tutoring, participation in the classes of other teachers, or classroom observation, required special training and visits to other schools or resource centers (EACEA/Eurydice, 2013).

In the case of the province of Leon, in the Resolution of April 2, 2013, the Deputy Ministry for Public Service and Modernization (BOCYL, 2013a), it is stated that those candidates who have passed the selection process of competition should make a period of supervised practice as part of their selection process and intended to check their suitability for teaching.

During this period of six months, teacher trainees must engage in training and integration organized by the rating committee, which consist of:

The qualifying committee will be responsible for evaluating the teacher trainee at the end of the process and to appoint tutor, in charge of overseeing the teacher trainees, proposed by the director from among those teachers with at least five years of service in a career, special dedication and efficiency in their professional work and they will be enabled in the specialty in which the applicant develops practices.

The tutor must advise and inform trainee teacher about the school plan, organization and functioning of both the school and its governing bodies, participation and coordination of teaching and educational programming.

In addition, you can attend classes imparted by the trainees teachers, allow them to attend classes and, as stated in Article 101 of the Organic Law of Education, and will have to share responsibility of the programming of teaching students with the novice master.

Once the trial period has ended, the agency commission must evaluate teachers in practice according to the reports issued by the tutor, the director (Table 1), or where appropriate, the inspector in charge of the center, responsible for training activities, and the capacity of memorazing of the probationer. 
In addition, the teacher trainees conduct a final report assessing their internship in matters relating to teaching-learning process, participation in collegiate and educational coordination bodies, in the center activities and in the coaching and mentoring centers.

Table 1. Indicators of teacher evaluation in practice (BOCYL, 2013b)

\begin{tabular}{ll}
\hline \multicolumn{1}{c}{$\begin{array}{c}\text { Indicators report for teacher } \\
\text { tutor }\end{array}$} & \multicolumn{1}{c}{ Code } \\
\hline $\begin{array}{l}\text { 1. Application of appropriate } \\
\text { educational programming }\end{array}$ & 1. Personal schedule Compliance \\
$\begin{array}{ll}\text { 2. Adaptation of programming to } \\
\text { students }\end{array}$ & $\begin{array}{l}\text { 2. Participation in school acti- } \\
\text { vities }\end{array}$ \\
$\begin{array}{l}\text { 3. Development of appropriate } \\
\text { methodological strategies }\end{array}$ & $\begin{array}{l}\text { 3. Participation in the activities } \\
\text { of the faculty and the educational } \\
\text { community }\end{array}$ \\
$\begin{array}{l}\text { 4. Model development and on- } \\
\text { going formative assessment }\end{array}$ & $\begin{array}{l}\text { 4. Ability to relationship and } \\
\text { communication with students and } \\
\text { families }\end{array}$ \\
$\begin{array}{l}\text { 5.Participation in team activities } \\
\text { or equipment cycle or the relevant } \\
\text { department }\end{array}$ \\
\begin{tabular}{l} 
6. Attention to diversity \\
\hline
\end{tabular}
\end{tabular}

As can be seen, despite not having concrete and specific training measures for the new faculty, we try to meet the needs of teachers through different supports, according to Esteve (2006) and Montero (2006), in their comments on the Eurydice report (2004) and the OECD (2005) indicate that the support offered in Spain is little more than a bureaucratic procedure with no real use for solving the real difficulties faced by teachers. As such they coincide with Eirín, García and Montero (2009), in stating that Spain does not have a state program for the initiation into teaching to meet the needs of new teachers, as can be seen from data collected in international reports such as Eurydice $(2004,2012)$ or the report produced by the OECD (2005).

\subsection{The present study}

With this context as a starting point, and aware of the relevance of the introduction into teaching for teaching professionals, as well as the importance of the experiences which these professionals undergo during their first period of work within the profession, we have designed a research activity which enables us to analyze the real situation as experienced by teachers of Primary Education within the Province of León, articulated around the following general objectives:

- To understand and explain how Primary Education teachers undergo their first teaching experiences.

And with the following specific objectives:

- To establish which are the training needs as expressed by novice teachers in the exercise of their profession.

- To analyze if there are differences in the perception of training needs based on teaching experience.

- To collect information on motivation levels, the measures developed to assist new teachers during their induction into teaching and the satisfaction felt by new teachers in relation to these measures.
- To determine the perceptions and experiences as made known by Primary teachers during their first years of teaching.

\section{METHOD}

The research is framed within a non-experimental methodology (Latorre, del Rincón, \& Arnal, 2005), and specifically within the so-called ex-post-facto methodology (Colás, Buendía, \& Hernández, 2009; Latorre et al., 2005), with a descriptive orientation and search for improvement. A questionnaire was chosen as the means of gathering information, this is justified by the fact that our work is carried out on situations, which arise, and that we describe what occurs, with no direct intervention over such situations. The data was collected on-line and hard copy questionnaires.

After revising, organizing and entering all the data, we proceeded to perform statistical analysis using statistical methods such as frequency, mean, a correlation coefficient test, and crosstabs Pearson chi-square test with SPSS 15 software.

\section{$2.1 \quad$ Instrument}

As stated above, for the collection of information we used a questionnaire. The construction of the questionnaire on the introduction into teaching started with a review of the tools used in other studies on the experiences of teachers during their induction into teaching (Cardona, 2008; Esteve, 1997; Jordell, 1985; Marcelo, 1991; Veenman, 1984). We found that most of these did not meet research expectations, as they consisted largely of studies related to the challenges and difficulties present in the early stages of teaching, and for this reason, we decided to construct an ad hoc tool.

We therefore developed a first version of the questionnaire using as a point of reference the main contributions derived from the theoretical foundations of the work, creating a tool composed of 63 items. These referring to demographic items, to the level of competence acquired in initial training in order to meet the demands of actual teaching and also with reference to the degree of satisfaction with the experiences, as well as the aid received during the practice phase, and the professional development of the teacher.

The justification of the questionnaire first underwent an analysis with regards to the validity of the content as a means of collecting the scope of the construct and its dimensions.

The validity of the content of the questionnaire was supported by the theoretical framework and the judgment of experts and consisted of evaluating the items initially proposed in relation to their pertinence, importance and uniqueness. Using the answers given by the experts, we proceeded to either get rid of or to retain items, using as elimination criteria all those which did not receive a mark of 3 in the importance section from at least 3 out of 5 experts, and which were neither unique nor pertinent for at least 3 out of the 5 experts. In this way the initial questionnaire was reduced to 51 items with five response options $(1=$ Do not know $/$ No answer $2=$ None; $3=$ Little, $4=$ Quiet a lot, $5=\mathrm{A}$ lot), which once again were submitted to a test of approval by experts, all of whom agreed with the use of this system.

With this structure we carried out a measurement of reliability, seeking consistency and accuracy. With this in mind we used Cronbach's Alpha and Guttmann's Two Halves methods. In Cronbach's Alpha we obtained a coefficient of 0.865, which justifies the conclusion that there is a high correlation, because as Bisquerra (1987) indicates, the values of Cronbach's Alpha are acceptable from 0.70 , considered to be good from 0,80 and ex- 
cellent when they exceed 0.90. In Guttmann's Two Halves we obtained a validity coefficient of 0.887 in the first half and 0.740 in the second. These results show us that we are in possession of a tool with a high level of reliability.

\subsection{Participants}

Our reference population consists of the total number of novice teachers (with less than 4 years of teaching experience) in the province of León in 2011 totalling to 502 teachers, according to data provided by the Provincial Department of Education of León.

From this population and through a stratified proportional probability sample with a confidence level of $95.5 \%(2 \sigma)$ and a margin of error of plus/minus 5 , the research sample was com-posed of 64 elements, from which we obtained data from 63 subjects, representing $98.5 \%$ of the total sample designed.

We thought it worthwhile to compare the data of novice teachers with that of experienced teachers (over 4 years teach-ing experience), in order to see if accumulated experience affects the perception of the first teaching experiences. Thus, starting from an initial sample of 63 elements, we obtained a production sample of 60 subjects, representing $95.2 \%$ of the total sample of experienced teachers.

Information was collected from the novice teachers by personally giving out the questionnaires to the participants in a Teacher Training Course during the practice period in November 2011. We also drew up an online version of the questionnaire in order to allow teachers from the province of León who had earlier been contacted by email to submit their answers.

Once we had the sample of novice teachers, we sent (by post or email) the questionnaire to experienced Primary teachers in the province of León until a sample similar to that of new teachers was obtained. Despite the high sample mortality obtained under this technique, as indicated by García Llamas, González Galán and Ballesteros Velásquez (2001), we believe this to be the most appropriate form to develop this research under the circumstances.

For the preparation of the data, we followed the classic outline developed by García Llamas et al. (2001), by which the data is treated and organized in order to be transformed and interpreted.

\section{RESULTS}

123 teachers participated in this study, of which $51.3 \%$ were new teachers (63 subjects) and $48.7 \%$ experienced teachers (60 subjects). In terms of gender, most, $75.7 \%$ are women. In both groups there is a greater presence of women (49 new teachers and 44 experienced teachers).

According to the time frameworks used in the sample 52.9\% of the teachers surveyed are aged between 31 and 40. In addition, the majority of both the novice $(52.4 \%)$ and the expert teachers $(66.6 \%)$ develop their work in rural public schools.

\subsection{Level of preparation acquired with which to face daily teaching activity}

One of the issues we have attempted to deal with in this piece of work is the level of preparation that teachers consider to have received during their initial training period to enable them to face their first teaching experiences. For this reason we have imagined a series of different situations (within the academic, educational, organizational and material areas, and within the areas of information technology and communication and of special education) in order to learn in which areas they believe they have received more extensive training. Similarly, we also wish to discover the areas in which these teachers have found to be more difficult due to they did not have a great training.

On an academic level, the new teachers considered that they had received sufficient training to face all of the situations given, with the exception of "motivating the students in class" $(52.4 \%$ of the responses grouped in the options of Nothing and Little). They state that the best training they have received is in aspects related to "Mastering the various subjects that I teach" $(61.9 \%$, grouped in the response options Quite a lot and A lot). On the other hand, the results of experienced teachers do not show large differences from those of novice teachers, claiming to have received good training to deal with the academic situations raised except those related to "motivating students in the classroom" $(53.3 \%)$. They do, however, believe that the best training they have received is that related to "Using different ways of assessing students" $(61.7 \%)$, instead of the option which was given by the new teachers.

With regards to the area of education, the new teachers consider that they have received good preparation for dealing with the different situations described in the questionnaire, highlighting those related to "Encouraging student participation in class activities" $(79.4 \%)$, so it follows that these factors have not presented any difficulty to the teachers in their work. In contrast, the views of experienced teachers are different given that around 53.3\% believe that they have not received adequate training for "Encouraging a positive learning climate in the classroom."

Regarding the initial training on organizational situations shown in the questionnaire, new teachers consider that they have received good preparation only in "Managing time to prepare lessons" $(50.8 \%)$, while $79.4 \%$ of the sample state that they lacked good initial training for "Facing the heavy workload." The opinions of experienced teachers differ in this respect, and $58.3 \%$ state that they have received adequate initial training for "Organizing the work in the classroom", with the task of "Performing bureaucratic tasks" $(80 \%)$ that which they believe they have received less satisfactory training.

In relation to what we have termed the social area, $54 \%$ of new teachers believe they have received a good preparation for "Creating a positive environment through respectful relationships with students", however over $80 \%$ of the respondents comment on their lack of training for "Interacting with management" (82.5\%). The experienced teachers agree that they have only received good training for "Creating a positive environment through respectful relationships with students" ( $65 \%)$, while $78.3 \%$ of experienced teachers believe the weakest point of their training was that of "liaising with the parents."

Within the area of information technology and communication, as in the organizational and social areas, novice teachers consider that they have only received adequate training in "Selecting the right materials for the development of the subject" (53.9\%), which is supported by $55 \%$ of the experienced teachers surveyed. On the contrary, while the new teachers claim that the largest training gaps in this area are related to "Mastering different teaching methods" (53.3\%), the experienced subjects believe the main area of deficit here is in the area of the "Use of Information Technologies and Communication in the classroom " $(56.6 \%)$.

Finally, in the area of Special Education $63.5 \%$ of new teachers consider that they have received good training for "Adapting teaching to individual differences"; an aspect which was corroborated by $55 \%$ of the experienced teachers. Both groups of teachers consider that they have received training which they believe to be deficient for "Detecting students with Special Educational Needs" 
(57.2\% of the novice subjects and $53.3 \%$ of the experienced teachers).

In Table 2 we summarize the answers which both novice and experienced teachers have given about their perceptions of their initial training concluding that novice teachers believe they have had a good preparation for their initial training for "Encouraging student participation in the activities class "(79.4\%)," Adapting teaching to individual differences " $(63.5 \%)$ and" Mastering the various subjects that I teach " $(61.9 \%)$, while experienced teachers say that the best initial training received is in "Using different ways of assessing students" (61.7\%), "Encouraging student parti- cipation in class activities" (63.3\%) and "Organizing work in the classroom " $(58 \%)$.

Similarly, and in view of the data shown in Table 3, we find that novice teachers perceive that during their initial training they have experienced shortcomings in aspects related to the ability to "Liaise with management" (82.5\%), "Coping with an excessive workload " $(77.7 \%)$ and "Facing problems with particular students " $(73 \%)$. In contrast, the perception of the experienced teachers revealed deficiencies in the initial training especially in "Performing bureaucratic tasks" (80\%), "Relationship with parents" (78.3\%), and in "liaising with the management team" (76.6\%).

Table 2. Summary of the situations in which teachers have received a greater level of training. Source: Authors

\begin{tabular}{|c|c|c|c|}
\hline Greater level of training for new teachers & $3+4$ & Greater level of training for experienced teachers & $3+4$ \\
\hline 1. Encourage student participation in class activities & $79.4 \%$ & 1. Use different ways to assess students & $61.7 \%$ \\
\hline 2. Adapting teaching to individual differences & $63.5 \%$ & $\begin{array}{l}\text { 2. Encourage student participation in classroom } \\
\text { activities }\end{array}$ & $63.3 \%$ \\
\hline 3. Master the different subjects that I teach & $61.9 \%$ & 3. Organize the work in the classroom & $58 \%$ \\
\hline $\begin{array}{l}\text { 4. Use different ways in order to assess students } \\
\text { Understand the causes that facilitate or hinder student learning }\end{array}$ & $57.2 \%$ & $\begin{array}{l}\text { 4. Select the content that I teach } \\
\text { Select appropriate materials for the development of } \\
\text { the material }\end{array}$ & $55 \%$ \\
\hline $\begin{array}{l}\text { 5. Promote a positive learning climate in the classroom } \\
\text { Adapt the content of subjects to the particular conditions of the class and } \\
\text { the specific needs of each student }\end{array}$ & $55.6 \%$ & $\begin{array}{l}\text { 5. Determine the level of student learning } \\
\text { Adapt the content of subjects to the particular condi- } \\
\text { tions of the class and the specific needs of each student }\end{array}$ & $53,4 \%$ \\
\hline
\end{tabular}

Table 3. Summary of the situations in which teachers have received a worst level of training. Source: Authors

\begin{tabular}{|c|c|c|c|}
\hline Less preparation beginners & $3+4$ & Less preparation experienced teachers & $3+4$ \\
\hline 1. Liaising with the management team & $82.5 \%$ & 1. Performing bureaucratic tasks & $80 \%$ \\
\hline 2. Coping with an excessive workload & $77.7 \%$ & 2. Relationship with parents & $78.3 \%$ \\
\hline 3. Facing problems with particular students & $73 \%$ & 3. Liaising with the management team & $76.6 \%$ \\
\hline $\begin{array}{l}\text { 4. Performing bureaucratic tasks interacting with other tea- } \\
\text { chers in the school }\end{array}$ & $71.5 \%$ & 4. Coping with an excessive workload & $75 \%$ \\
\hline 5. Relationship with parents & $66.7 \%$ & 5. Interacting with other colleagues in the school & $71.7 \%$ \\
\hline 6. Maintaining discipline in the classroom & $65.1 \%$ & 6. Managing time for preparation of classes & $70 \%$ \\
\hline 7. Knowing the student satisfaction with teaching & $60.3 \%$ & 7. Facing problems with particular students & $65 \%$ \\
\hline 8. Detect special educational needs students & $57.2 \%$ & 8. Engaging in the decision-making process at school level & $61.7 \%$ \\
\hline $\begin{array}{l}\text { 9. Engage in the decision-making process at school level } \\
\text { mastering different teaching methods }\end{array}$ & $54 \%$ & 9. Maintaining discipline in the classroom & $58 \%$ \\
\hline 10. Motivate students in class & $52,3 \%$ & $\begin{array}{l}\text { 10. Knowing the student satisfaction with teaching } \\
\text { Use Information and Communications Technology in the } \\
\text { classroom }\end{array}$ & $56,7 \%$ \\
\hline $\begin{array}{l}\text { 11. Organize the work in the classroom } \\
\text { Use Information and Communications Technology in the } \\
\text { classroom } \\
\text { Treat students in a differentiated and individualized way }\end{array}$ & $50,8 \%$ & $\begin{array}{l}\text { 11. Mastering different teaching methods } \\
\text { Motivate students in class } \\
\text { Encouraging a positive learning atmosphere in the classroom } \\
\text { Detect special educational needs students }\end{array}$ & $53,3 \%$ \\
\hline
\end{tabular}




\subsection{Evaluation of the early years of teaching experience}

More than half of all new teachers $(61.9 \%$ by adding the percentages of Good and Excellent options, from now on in the data referred to) say they are satisfied with the experience gained during the first year of teaching practice. This percentage rises to $65 \%$ in the case of experienced teachers. However, we cannot forget that $27 \%$ of new teachers have stated that their degree of motivation is Very Poor. The data also indicated that $57 \%$ of new teachers and $66.7 \%$ of experienced teaching staff say they are satisfied with the degree to which they have met the expectations they had before starting work as teachers.

When asked about their integration into the school in which they began to work as teachers, we observe that only $58.7 \%$ of new teachers rated their arrival at the school positively, compared to $73.3 \%$ of the experienced teachers. Similarly, $55.5 \%$ of new teachers and $68.4 \%$ of experienced staff feel that their teaching has been positively valued by the other members of the educational community, while $12.7 \%$ of the new teachers and $3.3 \%$ of the experienced ones believe that the educational community valued their work in a negative way.

More than half of the teachers surveyed, $53.9 \%$ of beginners and $63.4 \%$ of experienced teachers say they are satisfied with their teacher training, although in the case of new teachers we find a significant percentage, $23 \%$, who believe that their teacher training up to that moment has been very poor.

Finally, when asked if they are satisfied with the work they have carried out, $61.9 \%$ of the novice teachers believe that they are, but we must keep in mind that $22.2 \%$ of them considered themselves to be highly dissatisfied with their teaching. However, in the case of experienced teachers, we can see that $76.6 \%$ of these claim to be satisfied with the work carried out during the years in which they have been teaching, and it is important to note that more than half, $53.3 \%$, replied that they had experienced a high level of satisfaction.

\subsection{Training activities and their assessment}

With respect to the training activities undertaken by new teachers when they start out in teaching, we see that $50.8 \%$ of them have attended "training courses" and $17.5 \%$ received "advice".

Regarding TALIS (OECD, 2014), it is interesting that in Norway and Spain, the difference in participation rates is in favour of less-experienced teachers, who seem to be more active in professional development activities than are more-experienced teachers.

For $61.9 \%$ of the teachers who replied the training activities lived up to the expectations that the teachers had before starting to work as teachers, while only $12.7 \%$ felt that the training provided was not related to what they had expected.

It is also worth noting that $69.8 \%$ of teachers believe that the training activities are adequate for their actual teaching, and for $60.3 \%$ this actually meets the real needs which arise and which they encounter in their jobs. Also, however, it must be pointed out that $15.9 \%$ think otherwise. For $82.5 \%$ of new teachers these training activities have been significant, and have contributed to the acquisition of new knowledge that they have been able to incorporate into their teaching. Thus for $79.3 \%$ of the novice teachers these training activities have been able to improve to a maximum their teaching skills and have been useful when it came to addressing the different situations that they have come across in their teaching.
Finally, $76.5 \%$ of teachers said that the training activities helped them to improve their teaching. In the case of experienced teachers, $41.6 \%$ of these attended "training courses", while $21.6 \%$ also formed part of "work groups", and $56.7 \%$ of them considered that these had met up to their expectations. For $63.4 \%$ of new teachers, thanks to these activities they have managed to acquire new knowledge which they have then been able to implement in their teaching, enriching their work as teachers. $52.4 \%$ of experienced teachers considered these features to be of use, indicating that they have been useful as a means of coming to terms with situations they have had to face as teachers.

\subsection{Professional Development of the Teacher}

Although many of those who answered the questionnaire were still at the beginning of the stage of professional development we still asked a series of questions with the intention of discovering what perception teachers have with regards to the relevance that the period of initiation into teaching has in their development as teachers. $50.7 \%$ of new teachers (adding the percentages of response options and Disagree and Strongly Disagree) do not consider that beginners in the teaching profession have crises or suffer the so-called "reality shock" (Veenman, 1984), because they believe that what they find upon arrival in the school and in the classroom is no different from what they in fact expected, although $51.7 \%$ of experienced teachers believe that there is a "reality shock" when entering the classroom for the first time.

With regard to the change in ideals which according many articles new teachers suffer when they change from being students to becoming teachers, $55 \%$ of the novice teachers think that this is indeed so, noting that when arriving at the school for the first time the teacher changes her or his conception about the teaching profession. This contrasts with that of experienced teachers, $60 \%$ of whom said that they still held the same ideals that they had before starting to teach.

The perception of the figure of the teacher seems to remain stable over time, since $50.8 \%$ of new teachers and $56.7 \%$ of experienced teachers alike say they still perceived the figure of the teacher in the same way as they did when they were in their formative stages.

With regards to the mastery of basic aspects of the teaching profession, it is curious to observe how, while $60.4 \%$ of new teachers report that in many situations they consider that they do not have a clear mastery of elements that might be considered essential for teachers, $63.3 \%$ of experienced teachers positively rate the initial teacher training provided for the new teacher, noting that at the beginning of their careers in teaching new teachers demonstrate that they possess sufficient knowledge of the basics of their profession.

Both novice teachers (71.4\%) and experienced staff (58.3\%) agree that the greatest difficulties a teacher faces usually appear during the first years of the teaching career. Thus $76.2 \%$ of newcomers believe that the relevance of the difficulties will diminish over the years, as they accrue experience, which will allow them to positively develop their teaching.

When asked about how best to deal with these difficulties, $55.6 \%$ of new teachers believe that beginner teachers need more time than experienced teachers in order to be able to resolve such difficulties, while $63.3 \%$ of experts believe that experience is not a determining factor for one teacher to resolve $r$ a complex situation before another does so. 


\section{DISCUSSION AND CONCLUSIONS}

The results obtained in the development of our research establish that there exists a widespread perception that there are gaps in initial teacher training, which at times cause the inexperienced teacher to feel insecure and to manifest difficulties in dealing with organizational, social, material and technological situations, as well as in situations which require attention to diversity. Many of these difficulties become apparent when the teacher is obliged to interact outside the classroom, with the management team or parents, for example, situations for which there would seem to be a significant lack of training. These deficiencies in the initial training are not resolved in general terms either by experience or by complementary training, so they continue to influence negatively on the professional development of a teacher even when she or he leaves the stage of initiation into teaching.

We have observed in a general way how teachers in primary education show a degree of satisfaction with regards to their first steps in teaching and that, with the exception of a few minor situations their overall experience in their first year in teaching is regarded as being positive. As such it is worth noting that it is the experienced teachers who have a more positive perception about the possibilities and capabilities of new teachers within their first year in the profession. Along with this satisfaction the results reinforce the idea that teaching is a profession which is predominantly vocational, and that despite the shortcomings and difficulties, both novice and experienced teachers show high levels of motivation, verifying at every possible opportunity the fulfilment of the expectations generated when they first start out as teachers, while at the same time perceiving their satisfactory development as teachers.

This data, however, should not hide the fact that there still exists a significant group of teachers (about one third of all respondents) who indicate a deep dissatisfaction, low motivation and low value placed on the work they carry out, in addition to denouncing the deficiencies which exist in schools in relation to the reception of new teachers and training for the development of learning while actually working.

In this regard, we note, like Cardona (2008), that a review of training plans designed for teachers in the initiation stage is necessary in order to bridge the gap between the initial training received and the practical needs identified, as this forms an essential feature in any improvement in the quality of education as well as the professional and emotional well-being of teachers.

As in the rest of the country (Marcelo, 1999), the aids that are available for new teachers in León are confined essentially to the development of courses and training programs. These courses seek to guide and assist inexperienced teachers to respond appropriately to situations that they may have to face as teachers.

In the OECD countries, the percentage of teachers who claim to have participated in specific training programs for teaching reaches $90 \%$, being significantly higher in Spain $(97.5 \%)$. Over $97 \%$ of teachers report feeling well prepared for teaching work in Spain. In the OECD, this percentage is lower (90\%). These data do not correspond to the actual training of teachers (OECD, 2014).

Despite the positive valuation that these activities have received from new teachers, it is important to overcome the traditional format in which an expert gives across the "practical" content in a lecture (Ferrández \& Sarramona, 1987) in order to reach a more solid and complete program which is able to combine theoretical and practical experiences with the aim of addressing the shortcomings which have been detected in the training of new teachers.
A significant feature which we have found in our study is the denial by novice teachers of the existence of "reality shock" (Veenman, 1984), and they note that although there have been changes in the ideals and concepts that they held with regards to the teaching profession, in general they continue to perceive the teacher in the same as way they did before starting to work. This premise assumes that the novice teachers interviewed have not yet lived through or have not yet internalized this situation, as most experienced teachers claim to have undergone "reality shock" (Veenman, 1984). Thus experienced teachers say that, after their first experience as teachers, there were substantial changes in the conceptions they held regarding the reality of teaching and classroom work in comparison to those they had at the end of their initial training period. This group, however, also said that despite these changes they continued to maintain an image which was similar to the one they had before starting to work as teachers on the ideals that govern the teaching profession and the image of the teacher.

Another finding that should be highlighted is related to the mastery of the basic aspects that shape the teaching profession. In this regard, most novice teachers state that during their first years of teaching they have to deal with certain situations which make them aware that they have a sufficient command of many of the elements that are essential for their professional development as teachers. From the point of view of experienced teachers, however, this discussion suffers from a high degree of self-criticism, given that in their majority they value positively the initial training which teachers have regarding the mastery of features which might be regarded as basic for carrying out the teaching profession.

The results we have obtained also allow us to indicate that both beginners and experienced teachers agree that the greatest difficulties usually found by a teacher usually appear at the stage of initiation into teaching, and this is largely due to the lack of expertise, when facing new and unfavourable contexts etc., which many new teachers have to face upon arriving at a school for the first time. In this context, while new teachers believe that these difficulties will diminish over time because experience will improve their ability to deal with them, experienced teachers say that experience is not related to the existence of difficulties in teaching, although it does contribute to coping with them.

Given the above, and synthesizing our results with those obtained in other studies, we believe that we should take advantage of the reformulation and expansion of initial training of future teachers to include in the new degrees contents related to the features which are shown to have the greatest deficiencies in training and which are largely related to educational aspects and aspects related to interpersonal relationships both within the classroom and without. In this same respect, it also seems obvious to point out that the redesigning of training programs for the initiation stage goes through complementing the initial training in practical aspects for teachers and that these courses should be taken by all teachers who start working in our schools, not just those who have passed the competitive selection process.

In this context we also recommend schools to develop their own programs for the reception of new teachers which allow them to get to know and familiarize themselves with their working environment, reducing thereby the negative effects produced when a new teacher is faced with new situations in unknown environments.

The main limitation of this study lies in the fact that the work was carried out within one specific region with its own specific legislation within Spain, and as such, in order to improve fur- 
ther research, it would be desirable to extend this concern to other geographical areas, including a study within the European framework.

\section{REFERENCES}

Bartlett, L., \& Johnson, L. S. (2010). The evolution of new teacher induction policy: Support, specificity, and autonomy. Educational Policy, 24(6), 847-871. doi:10.1177/0895904809341466

Bickmore, S. T., \& Bickmore, D. L. (2010). Revealing the administrator's role in the induction process: Novice teachers telling their stories. Journal of School Leadership, 20, 445-469. Retrieved from http://www.sciencedirect.com/science/article/pii/S0742051X09002418

Bickmore, D. L., \& Curry, J. (2013). The induction of school counselors: Meeting personal and professional needs. Mentoring and Tutoring: Partnership in Learning, 21, 6-27. doi:10.1080/13611267.2013.784057

Bisquerra, R. (1987). Introducción a la estadistica aplicada a la investigación educativa. Un enfoque informático con los paquetes BMDP y SPSSX. Barcelona: PPU.

Cardona, J. (2008). Problemática actual del profesorado: Algunas soluciones. Enseñanza \& Teaching, 26, 29-56.

Colás, Mª P., Buendía, L., \& Hernández, F. (2009). Competencias científicas para la realización de una tesis doctoral. Barcelona: Davinci.

Comisión Europea/EACEA/EURYDICE (2013). Cifras clave del profesorado y la dirección de centros educativos en Europa. Luxemburgo: Oficina de Publicaciones de la Unión Europea.

Corbell, K. A., Osbourne, J., \& Rieman, A. J. (2010). Supporting and retaining beginning teachers: A validity study of the perceptions of success inventory for beginning teachers. Educational Research and Evaluation: An International Journal on Theory and Practice, 16(1), 75-96. doi:10.1080/13803611003722325

Cuddapah, J. L., \& Burtin, A. S. (2012) What All Novices Need. Educational Leadership, 69(8), 66-69.

Curry, J. R., Webb, A.W., \& Latham, S. J. (2016). A Content Analysis of Images of Novice Teacher Induction: First-Semester Themes. Journal of Educational Research and Practice, 6(1), 43-65.

Darling-Hammond, L. (2010). Recruiting and retaining teachers: Turning around the race to the bottom in high-need schools. Journal of Curriculum and Instruction, 4(1), 16-32. doi:10.3776/joci.2010.v4n1p16-32

Darling-Hammond, L., \& Bransford, J. (2005). Preparing teachers for a changing world: What teachers should learn and be able to do. San Francisco, CA: John Wiley \& Sons.

Eirín Nemiña, R., García Ruso, M., \& Montero Mesa, L. (2009). Desarrollo profesional y profesionalización docente. Perspectivas y problemas. Profesorado: Revista de Curriculum y formación del profesorado, 13(2), 1-13. Retrieved from http://www.ugr.es/ recfpro/rev132COL3.pdf

Esteve, J. M. (1997). La formación inicial de los profesores de secundaria. Barcelona: Ariel.

Esteve, J. M. (2006). La profesión docente en Europa: perfil, tendencias y problemática. La formación inicial. Revista de educación, 340, 19-40.

European Commission/EACEA/Eurydice (2015). The Teaching Profession in Europe: Practices, Perceptions, and Policies (Report). Luxembourg: Publications Office of the European Union.

Eurydice (2002). The teaching profession in Europe: profile, trends and concerns. Key topics in Education in Europe (Report). Brussels: Eurydice.

Eurydice (2004). The teaching profession in Europe: Profile, trends and concerns. Report IV: Keeping teaching attractive for the 21st century (Report). Brussels: Eurydice.

Eurydice 2012. Key Data on Education in Europe 2012 (Report). Retrieved from http://eacea.ec.europa.eu/education/eurydice/documents/key_data_series/134EN.pdf

Feiman-Nemser, S. (2001). Helping Novices Learn to Teach. Lessons from an Exemplary Support Teacher. Journal of Teacher Education, 52, 17-30. doi:10.1177/0022487101052001003

Feiman-Nemser, S. (2003). What new teachers need to learn. Educational Leadership, 60, 25-29.

Feiman-Nemser, S. (2012). Teachers as Learners. Cambridge, MA: Harvard Education Press.

Ferrández, A., \& Sarramona, J. (Eds.) (1987). Didáctica y tecnología de la educación (Diccionario de Ciencias de la Educación). Madrid: Anaya.

García Llamas, J. L., González Galán, M. A., \& Ballesteros Velásquez, B. (2001). Introducción a la investigación en educación. Madrid: UNED.

Gold, Y. (1996). Beginning Teacher Support. Attrition, mentoring, and induction. In J. Sikula, (Ed.). Handbook of Research on Teacher Education. Association of Teacher Educators (pp. 548-594). New York: Macmillan.

Harris, K., Jenz, F., \& Baldwin, G. (2005). Who's teaching science? Meeting the demand for qualified science teachers in Australian secondary schools. Report pre- pared for Australian Council of Deans of Science. Melbourne, Australia: Centre for the Study of Higher Education, University of Melbourne.

Henry, G. T., Bastian, K. C., \& Fortner, C. K. (2011). Stayers and leavers: Early-career teacher effectiveness and attrition. Educational Researcher, 40(6), 271-280. doi:10.3102/0013189X11419042

Hobson, A. J., Ashby, P., Malderez, A., \& Tomlinson, P. D. (2009). Mentoring beginning teachers: What we know and what we don't. Teaching and Teacher Education, 25(1), 207-216. doi:10.1016/j.tate.2008.09.001

Howe, E. R. (2006). Exemplary teacher induction: An international review. Educational Philosophy and Theory, 38(3), 287-297. doi:10.1111/j.14695812.2006.00195.x

Hudson, P. (2012). How Can Schools Support Beginning Teachers? A Call for Timely Induction and Mentoring for Effective Teaching. Australian Journal of Teacher Education, 37(7). doi:10.14221/ajte.2012v37n7.1

Huling, L., Resta, V., \& Yeargain, P. (2012). Supporting and retaining novice teachers. Kappa Delta Pi Record, 48(3), 140-143. doi:10.1080/00228958.2012.707 532

Hunter (2016). New Teacher Induction: A Program Evaluation (Dissertation). The College of William and Mary, University of Williansburg. Retrieved from http:/ publish.wm.edu/cgi/viewcontent.cgi?article $=1014 \&$ context $=$ etd

Imbernón, F. (1994a). La formación del profesorado. Barcelona: Paidós.

Imbernón, F. (1994b). La formación y el desarrollo profesional del profesorado. Hacia una nueva cultura profesional. Barcelona: Graó.

Imbernón, F. (2007). La formación permanente del profesorado. Nuevas ideas para formar en la innovación y el cambio. Barcelona: Graó.

Ingersoll, R. (2006). Understanding supply and demand among mathematics and science teachers. In J. Rhoton \& P. Shane (Eds.), Teaching science in the 21 st century (pp. 197-211). Arlington, VA: NSTA Press.

Ingersoll, R. (2012). Beginning teacher induction: What the data tell us. Phi Delta Kappan, 93, 47-51. doi:10.1177/003172171209300811

Jonson, K. F. (2002). Being an effective mentor: How to help beginning teachers succeed. Thousand Oaks, CA: Corwin Press.

Jordell, K. (1985). Problems of beginning and more experienced teachers in Norway. Scandinavian Journal of Educational Research, 29(3), 105-121. doi:10.1080/0031383850290301

Kemmis, S., Heikkinen, H. L. T., Fransson G., Aspfors, J., \& Edwards-Groves, C. (2014). Mentoring of new teachers as a contested practice: Supervision, support and collaborative self-development. Teaching and Teacher Education, 43, 154164. doi:10.1016/j.tate.2014.07.001

Kidd, L., Brown, N., \& Fitzallen, N. (2015). Beginning Teachers' Perception of Their Induction into the Teaching Profession. Australian Journal of Teacher Education, 40(3), 153-173. doi:10.14221/ajte.2014v40n3.10

Latorre, A., del Rincón, D., \& Arnal, J. (2005). Bases metodológicas de la investigación educativa. Barcelona: Ediciones Experiencia.

Le Maistre, C., \& Paré, A. (2010). Whatever it takes: How beginning teachers learn to survive. Teaching and Teacher Education, 26(3), 559-564. doi:10.1016/j. tate.2009.06.016

Luft, J. A. (2007). Minding the gap: Needed research on beginning/newly qualified science teachers. Journal of Research in Science Teaching, 44(4), 532-537. doi: $10.1002 /$ tea. 20190

Marcelo, C. (1991). Aprender a enseñar. Un estudio sobre el proceso de socialización de profesores principiantes. Madrid: CIDE.

Marcelo, C. (1999). Formación de profesores para el cambio educativo. Barcelona: EUB.

Marcelo, C. (2009). Los comienzos en la docencia: Un profesorado con buenos principios. Profesorado: Revista de Currículum y Formación del Profesorado, $13(1), 1-25$.

Montero, M. L. (2006). Profesores y profesoras en un mundo cambiante: el papel clave de la formación inicial. Revista de educación, 340, 66-86.

Nasser-Abu Alhija, F., \& Fresko, B. (2010). Socialization of new teachers: Does induction matter? Teaching and Teacher Education, 26(8), 1592-1597. doi:10.1016/j.tate. 2010.06 .010

OCDE. (2005). Teachers matter: attracting, developing and retaining effective teachers (Report). París: OCDE. Retrieved from http://www.oecd.org/docume nt/9/0,3746,en $264939263231 \quad 11969545 \quad 1 \quad 1 \quad 1 \quad 1,00 . h t m l$

OECD (2014). TALIS 2013 Results. An International Perspective on Teaching and Learning. Teaching and Learning International Survey (Report). OECD Publishing. doi:10.1787/9789264196261-en

Real Decreto 276/2007, de 23 de febrero, por el que se aprueba el Reglamento de ingreso, accesos y adquisición de nuevas especialidades en los cuerpos docentes a que se refiere la Ley Orgánica 2/2006, de 3 de mayo, de Educación, y se regula el régimen transitorio de ingreso a que se refiere la disposición transitoria decimoséptima de la citada ley. Boletín Oficial del Estado, 53, Madrid, 2 de marzo de 2007.

Resolución de 2 de abril de 2013a, de la Viceconsejería de Función Pública y Modernización, por la que se convoca procedimiento selectivo de ingreso, de adqui- 
sición de nuevas especialidades y de baremación para la constitución de listas de aspirantes a ocupar puestos docentes en régimen de interinidad en el cuerpo de maestros. Boletín Oficial de Castilla y León, 67, 9 de abril de 2013, núm. 67.

Resolución de 13 de septiembre de 2013b, de la Dirección General de Recursos Humanos de la Consejería de Educación, por la que se regula la fase de prácticas de los aspirantes seleccionados y nombrados funcionarios en prácticas derivados del procedimiento selectivo de ingreso convocado por Resolución de 2 de abril de 2013, de la Viceconsejería de Función Pública y Modernización. Boletín Oficial de Castilla y León, 183, 23 de septiembre de 2013.

Saka, Y., Southerlands, A., Kittleson, J., \& Hutner, T. (2013). Understanding the Induction of a Science Teacher: The Interaction of Identity and Context. Research in Science Education, 43, 1221-1244. doi:10.1007/s11165-012-9310-5

Skilbeck, M., \& Connell, H. (2003). Attracting, developing and retaining effective teachers. Canberra, Australia: Commonwealth Government of Australia. Retrieved from www.oecd.org/ dataoecd/63/50/3879121.pdf

Smith, T. M., \& Ingersoll, R. M. (2004). What are the effects of induction and mentoring on beginning teacher turnover? American Educational Research Journal, 41, 681-714. doi:10.3102/00028312041003681

Sundli, L. (2007): Mentoring - A new mantra for education? Teaching and Teacher Education, 23(2), 201-214. doi:10.1016/j.tate.2006.04.016

Veenman, S. (1984). Perceived problems of beginning teachers. Review of Education of Research, 54(2), 143-178. doi:10.3102/00346543054002143

Villani, S. (2009). Comprehensive mentoring programs for new teachers: Models of induction and support. Thousand Oaks, CA: Corwin.

Vonk, J. (1996). A knowledge base for mentors of beginning teachers: Result of a Dutch experience. In R. Mcbridge (Ed.), Teacher education policy (pp.112-134). London: Falmer Press.

Wechsler, M. E., Caspary, K., Humphrey, D. C., \& Matsko, K. K. (2012). Examining the effects of new teacher induction. Yearbook of the National Society for the Study of Education, 111(2), 387-416.

Wong, H. (2004). Induction programs that keep new teachers teaching and improving. NASSP Bulletin, 88(638), 41-59. doi:10.1177/019263650408863804

Zaragoza, J., Generelo, E., \& Julián, J. A. (2008). Innovación docente en el marco universitario: una experiencia en el contexto de la formación inicial del maestro especialista en Educación Física. REIFOP, 8(4). Retrieved from http://www.aufop.com/aufop/uploaded_files/articulos/1229709255.pdf

Zepeda, S., \& Mayers, R. (2001). The new kids on the block schedule: Beginning teachers face challenges in schools. The High School Journal, 84(4), 1-11. doi:10.1353/hsj.2001.0014

How to cite this article: Cañón, R., Cantón, I., Arias, A. R., \& Baelo, R. (2017). Initiation into Teaching from the Perspective of Primary School Teachers: Differences Between Newly Qualified and Experienced Teachers. Journal of New Approaches in Educational Research, 6(2), 103-111. doi: 10.7821/naer.2017.7.202 